\title{
The Proliferation of Men: Markets, Property, and Seizure in Jordan
}

\author{
Geoffrey Fitzgibbon Hughes
}

London School of Economics

\section{ABSTRACT}

Spurred on by massive influxes of Palestinian refugees in previous decades, the 1970s and 1980s were marked by acute struggles over land and housing in Jordan. This article places those struggles within the context of a historical look at property in Jordan spanning from the dissolution of the Ottoman Empire to more recent waves of refugees from Syria and Iraq. Drawing on recent research in the social studies of finance and feminist substantivist critiques of "the economy," I argue for more attention to the role of violence and war in the formation of markets and property regimes. Moving between a World Bank squatter settlement standardization program and interviews with contemporary planners, speculators, homeowners, and construction workers, I argue that the sublimation of violent contestation over property has required subtle but important transformations in gender norms that privilege new strategies of accumulation. Yet many of my interlocutors insist that this novel "proliferation of wealth" remains subordinate to the role of large agnatic kin groups in the communal defense of land ("the proliferation of men"). Ongoing struggles between financiers, agnatic kin groups, and the Jordanian state illustrate the ways in which seizure is key to the work of market formation. [Keywords: Infrastructure, squatter settlements, settler colonialism, violence, kinship, masculinity] 
$\mathrm{T}$ he first time I heard the proverb 'izwat ar-rijāl ahsan min 'izwat al-māl (the proliferation of men is better than the proliferation of wealth), I was talking to my friend Abu Mahmud about his life story. Over 80 , he was about five feet tall with a long bushy white beard and kind eyes. We talked about his family: his nine sons and their various jobs, mostly in security services. As we sat on the porch, he gestured down the winding road to their respective houses. He had helped build dwellings for all of them in the neighborhood so that they would always be nearby. He told me about how the whole settlement-now a dense concrete honeycomb-had started decades ago with three men: his Jordanian Bedouin father along with two men who were fleeing Palestine. Explaining how he had earned the money to build these houses, Abu spoke of his work in construction and the shift from goat hair tents woven by women to concrete houses built with male wealth and labor. He reminisced about the various families whose houses he had built, displaying his pride in a lifetime of hard work. At one point, he took my hand and placed it on his shoulder so I could feel the deep groove formed by decades of carrying things on his back. He emphasized to me that he was a simple, God-fearing man who was

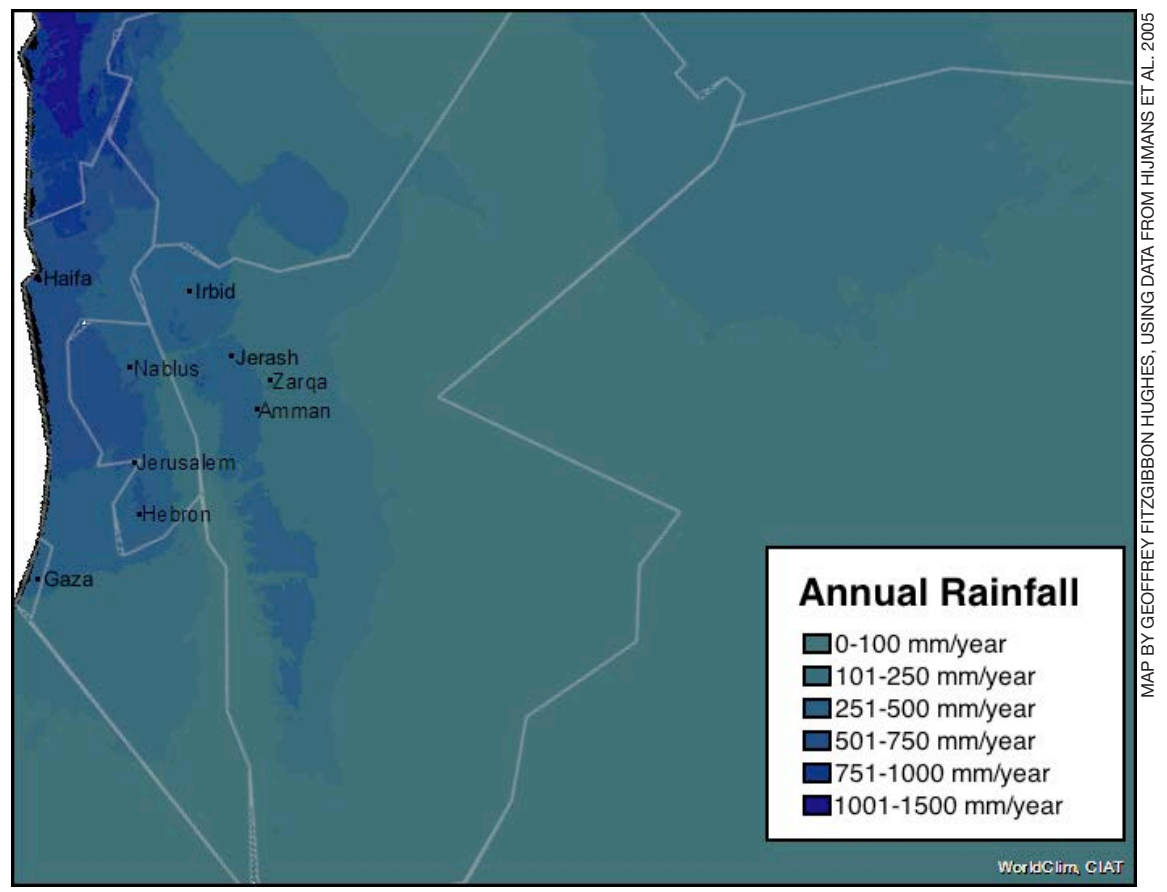

Figure 1: A map of Jordan and its annual rainfall, based on data from Hijmans. 
at peace with his place in the world, viewing his family and its proliferation of men as his greatest accomplishment. As far as Abu Mahmud was concerned, this was as it should be.

This article traces the development of a giant, unplanned, and at times downright illegal construction project involving successive waves of refugees who have sought shelter and legal recognition in Jordan. Jordan's young capital, Amman, rises from the bedrock as limestone is ground up into concrete, pressed into cinderblocks, and built into houses that can be occupied by families dreaming of stable sanctuaries where they may safely dwell and prosper. As fathers seek to help build homes for their sons and grandsons, the network of concrete structures becomes denser and more interconnected: male kinship relations and community are materially instantiated in the built environment as each successive generation builds homes for the next generation around the existing structures. Yet the assemblage remains partial, incomplete, and vulnerable to seizure. Unfinished structures litter the landscape, and aspirational concrete pillars jut out from people's roofs. Those who build without government approval run the risk of being labeled "squatters" and having their homes demolished. Locals frustrate wealthy interlopers by making off with the plumbing in the night.

The key to this story is the notion of seizure. Most notable here are the violent, overt seizures of large swaths of land by the Israeli state, which drove hundreds of thousands from the verdant lands west of the Jordan River to the far less forgiving steppe to the east. However, the focus of the article is the subsequent, much more subtle, and even sublimated forms of seizure that have been crucial to the attempts of those dispossessed and their sometimes reluctant hosts to reestablish some sense of normalcy. It is a privilege to be relieved of the work of seizure in this context. This includes the work that long-time East Bankers [Jordanians] have put into occupying their land and later selling it to their West Banker [Palestinian] "guests." It also includes the Jordanian government's ongoing attempts to claim such land for itself. At its most abstract, we find a massive World Bank infrastructure loan to the Jordanian government designed to fix such property relations once and for all and provide basic infrastructure to socalled "squatters" - on the condition that those labeled as squatters repay the initial loan with interest.

The notion of seizure, so central to early utopian socialist writings on market formation and economy (cf. Proudhon 1994, Marx 1976), has tended to 
fall out of more recent work on the social construction of markets (Callon 1998, MacKenzie 2009, Miyazaki 2005). Ironically, despite these more recent authors' emphasis on the state's role in market formation, one rarely finds the state fully exercising its hallmark repressive powers in their accounts. However, by moving from cosmopolitan centers of accumulation and their relatively privileged denizens (Ho 2009, MacKenzie 2006, Zaloom 2006) to more peripheral frontier zones, we can see how violently conflicting notions of value, ownership, and legitimate authority are harnessed to constitute contemporary forms of property and market relations. ${ }^{1}$ Of course, the line between center and periphery today is often quite stark and abrupt. Some of the most notable urban political struggles in recent years in some of the world's most supposedly advanced democracies and economies have involved highly profitable state initiatives of, on the one hand, "graying" (Yiftachel 2009) marginalized spaces and populations to render them illegal and, on the other hand, "legaliz[ing] the illegal" (Holston 2007:25). The Marxist geographer David Harvey (2003), writing about this apparent lacuna within contemporary social scientific literature in the era of gentrification, has suggested greater attention to "accumulation through dispossession" as a corrective. Drawing on the work of Rosa Luxemburg (2003), Harvey argues that the emphasis on an originary or "primitive" accumulation in the writings of Marx and many of his latter-day interpreters has distracted social scientists from focusing on the ways in which the demands of accumulation constantly require the production of new frontiers that can be incorporated-anew - into capitalist production. ${ }^{2}$

To understand how these forms of what Bear et al. (2015) term "capture and conversion" function and how they are effaced, it is useful to return to the tradition in anthropology of feminist substantivist critiques of attempts to disembed "the economy" and constitute it as a discrete "social domain." In Naturalizing Power, Sylvia Yanagisako and Carol Delaney critique this tendency to view "the quartet of kinship, economics, politics, and religion" as "basic building blocks of society" in favor of "read[ing] across these domains" (1995:11-14). By doing so we learn that, for instance, "too many studies of women's 'domestic' activities have disclosed that these have political as well as domestic consequences" (Yanagisako 1979:191). As we will see, the reverse is equally true: men's supposedly political-jural activities often have important domestic ramifications. All too often these activities - whatever their "domain"-lead to the socially legitimated alienation of some people's productive and reproductive capacities by some others. 
However, the impressions that social actors (ethnographers included) derive from their experiences of such "domains" are unlike those associated with what Yanagisako and Delaney (1995) term "explicit ideologies." This is because direct experience itself seems to validate a close correspondence between the discrete social institutions one encounters and "hegemonic cultural distinctions." Recognizing this form of reification forces us to ask, "how culturally specific domains have been dialectically formed and transformed in relation with other cultural domains, how meanings migrate across domain boundaries, and how specific actions are multiply constituted" (1995:11-12). This is why it can be difficult for ethnographers to write simultaneously about both the peaceable "economic" marketing of commodities and the violent "political" exclusion of other possible claimants that makes those "peaceable" market relations possible. ${ }^{3}$ Trade, barter, trickery, development, and construction inevitably partake in broader logics of seizure. We cannot disembed such putatively "economic" issues associated with property and market-formation from putatively "political" action based on coercive rationality.

My interlocutors largely refused to treat landed property as what most would consider a purely "economic" phenomenon, often emphasizing what we might call its violent, political dimension (seizure) and their complicity in it as men. In conversations about land, men like Abu Mahmud frame relations between men as vastly more important than relationships between things. Tellingly, Abu Mahmud would never explain to me who his father and friends had bought the land from - not that it was difficult to find out from our other neighbors. Instead, attempts at elicitation inevitably caused him to launch into stories about the great, masculine exploits of his ancestors ("real men") or, if pressed, he might exclaim in exasperation, min nās (from people). Of course, compared to the forced expulsion of the Palestinians from their homes and the invocation of eminent domain by the Jordanian state and global development experts, the attempts of Abu Mahmud and other Jordanians to simply dwell in the world with their families are strikingly benign and sentimental. Yet his valorization of the "proliferation of men" and his refusal to allow his ownership claims to be fully assimilated to the "economic" category of private, freehold property were compelling.

This article narrates a particular struggle amongst agnatic kin groups, the Jordanian state, and transnationally situated financiers over the nature and disposition of markets and property. To do so, it is necessary to 
track backwards and forwards in time and space between government offices and the physical terrain upon which people have long staked their respective property claims. The first section introduces the deeper history of contestation over the "enclosure" of land by the state, those allied with it, and those opposed to it. The second section introduces "The Shelter Unit" and their archives: remnants of a World Bank squatter settlement standardization initiative that sought to constitute and rationalize a national housing market in Jordan. The next section contrasts the idea of ownership that emerged from the Shelter Unit's efforts with those that had come before, highlighting its deeply individuated notion of ownership. The fourth and fifth sections address how lands in the wastelands that were once "free" could be reinvented, with the help of the World Bank, their knowledge-production, and their infrastructure loans, as a source of value for global commodity markets through techniques of "squatter settlement standardization." Throughout this process, seizure has remained key to the various attempts of different groups to press their property claims and further their respective infrastructure projects.

\section{Enclosures}

The following account draws on a combination of oral historical research, participant observation, and archival research in Jordan. Archives at the Housing and Urban Development Corporation, one of the main institutions that emerged from the implementation of the World Bank's squatter settlement standardization program, held a wealth of reports from the United Nations, the World Bank, the Housing Corporation, the Ministry of Planning, the Ministry of Municipal and Rural Affairs, and the Urban Development Department. All of these sources reflect traces of a sensibility that transcends the particularities of any specific historical legal property regime: unimproved steppe land is there for the taking and land rights are a function of one's physical, material engagement with the land and a willingness to defend one's claim. Even at the time of research, outsiders who bought land in the arable zone where legal questions of ownership were supposedly settled decades ago-almost always wealthy urbanites building filas (villas) - invested enough money in staking a physical claim to their new property to suggest a widespread lack of faith in the adequacy of legal title alone. In fact, to what degree any particular property regime has ever functioned de facto or de jure in what is now Jordan is 
a matter of debate. Oral historical and journalistic accounts of the postOttoman era are full of examples of land transfers that were not recorded in government-issued land deeds (sanads). To this day, the privatization and commoditization of land in Jordan remains a partial-if increasingly successful-project, which the World Bank, United Nations, and Housing Corporation continue to promote with mixed results.

Michael Fischbach's (2000) study of the documentary evidence concerning land rights in the 19th and 20th centuries describes an Ottoman land regime 4 in which very little land outside of urban areas was private, freehold land (mulki) and the vast majority of land was the property of the state ( $m$ iri $)$. Such land was there to be improved and used by subjects in return for taxes. By working the land, Ottoman subjects gained rights to the fruits of the land (tașarrif, or usufruct), but the "neck" (al-ruqba, or ultimate ownership) continued to reside with the state and served as the basis for taxation. Fischbach (2000) argues that it was with the onset of British rule that property relations in Jordan's agricultural regions really started to shift towards a regime of private, freehold land tenure. He claims that, for the British, there were "two fundamental assumptions. The first was that all land was owned by someone. The second was that land should be managed efficiently in order to maximize its productive potential" (2000:79). The cadastral surveys the British conducted in the wake of their conquest of the Ottoman Empire sought to institutionalize private property with a precision that had never been attempted before. ${ }^{5}$ All cultivated land was to be assigned by the state to individuals - even if the ownership of uncultivated land remained ambiguous. Practically speaking, this meant that the state made a point of registering the fertile land near the Jordan Valley to individuals while quietly claiming everything else for itself - a decision that would later prove untenable.

The process through which interlopers secured their newly acquired property was one of enclosure (cf. Polanyi 1944), and followed a formulaic pattern. The new owner would start by erecting a fence around the parcel. At times, these fences could appear rather symbolic: chicken wire or something consciously resembling the pre-modern boundary walls that dot the landscape in the Jordan Valley and its hinterland. These days, fences built by wealthy interlopers tend to be over two meters tall. In contrast, people with ties to the area inevitably built the other way around: building the house first and then worrying about demarcating boundaries and shielding the house from view to conform to community norms of modesty. 
Having built a fence, however, newcomers would often plant some sort of crop within the enclosure and leave it otherwise vacant for years. In the arable zone west of Amman, this led to a common sight of small plots of wheat or baby olive trees sitting behind massive fences made of either concrete faced with cut stone or chain link-often topped with barbed wire. The wealthiest would bring in grown fruit trees, ${ }^{6}$ hire a migrant laborer from Egypt or Syria to look after them, and then hire a second man (one with deep roots in the community) to look after the estate and the migrant laborer. All of these behaviors were readily recognized by local residents (old-timers and newcomers alike) as strategies for staking a claim to ownership that ran orthogonal to the state-backed regime of land registration.

Despite this widespread and ongoing lack of faith in the regime of land registration, the 1970s and 1980s constituted a crucial time period for the future of housing in Jordan during which large swaths of tribally controlled land were transformed into partible commodities that could be bought, sold, and circulated due to a sophisticated regime of registration, zoning and infrastructure provision. This process of commoditization ${ }^{7}$ (Appadurai 1988) involved the creation of a very specific sort of regime of value that was catalyzed by an international group of planners ${ }^{8}$ known as "the Shelter Unit" who sought to fix what they perceived as Jordan's housing problem by establishing an efficient housing market. To the degree that they succeeded in using ongoing political tensions between Palestinian refugees, the residents of the East Bank, and the government to create enough affordable, state-certified properties to constitute a housing market, they created a new regime of value. The kind of fluid, efficient housing market they envisioned could have far-reaching implications for the relationship between men, their families, their agnatic kin groups, and the state. What seems to have emerged, though, is a much messier compromise among a range of competing regimes of value.

\section{The Shelter Unit}

The Jordan of the development reports stored at the Housing Corporation would be almost unrecognizable to most Jordanians. As Michael Goldman (2005) makes clear in his ethnography of the World Bank, Imperial Nature, knowledge production at the organization is largely beholden to the requirements of providing global financial markets with guaranteed, high-yield, credit-based investments. The Bank has neither the time nor the resources 
to focus on anything other than generating returns for its investors in the most efficient way possible. Thus, major divergences between Bank reports and anything that local people might identify as "reality" should not be completely surprising. For example, where oral historical accounts of land tenure in Jordan were largely dominated by a narrative that emphasized the tensions between Palestinian refugees and their Jordanian hosts, the country's two World Bank-financed National Housing Strategies (from 1987 and 1996 respectively) went out of their way to avoid the controversy ${ }^{9}$ - while making proposals that would ultimately transform the relationship between the two groups. This is exactly what Goldman's account of higher-level decision-making processes at the Bank would predict. It is also deeply consonant with James Ferguson's (1994) widely respected study of World Bank development discourse in Lesotho in the 1980s, The Anti-Politics Machine. Of course, with the exception of their common proximity to a settler colony, there is little reason why events in the 1970s and 1980 s in Lesotho should have any particular bearing on events in Jordan. The countries are vastly different and separated by thousands of miles, but this would not be particularly apparent from the reports. In keeping with Goldman's observations about knowledge production at the Bank a decade later, the development programs essentially employ the same framework no matter where they are applied. This implies there is both congruity between the Jordanian reports and their counterparts across the globe and incongruity between the Jordanian reports and the oral historical evidence. This encourages us to interpret such reports as a reflection of the sensibilities of transnationally situated planners rather than a straightforward and authoritative account of historical events in a given locale.

As Goldman and Ferguson argue, it is beside the point that these reports inevitably turn out to be internally inconsistent and factually inaccurate. To quote Ferguson, "the statistics are wrong, but always wrong in the same way; the conceptions are fanciful, but it is always the same fantasy" (1994:55). The 1986 National Housing Strategy, prepared by the Shelter Unit in concert with a consultancy called Planning and Development Collaborative International (PADCO), is typical. In keeping with the liberalizing, "small government" ethos of the Reagan-Thatcher era, the strategy proposal cautioned against housing projects and suggested that "the preferred strategy relies primarily on the private sector and, in particular, the individual, owner-builder housing path to achieve targets in both total national housing production and production appropriate for all income 
groups" (Shelter Unit 1987a:24). However, once one finished the executive summaries and waded into the next 23 volumes, the report was padded with all sorts of perceptive work by indigenous planners-much of which completely contradicted the top-line findings of the report. For instance, the same report that conceptualizes housing as the work of "individual owner-builders" later reproduces a model (in Volume 7) from the Urban Development Department that treats housing as the work of kin-based collectivities centered around apical male ancestors (like Abu Mahmud) working and living together. The chart includes five columns, listing the age of the household, the age of the head of household, "family milestone[s]" (when the sons are born, start work, and get married), the "number of workers in basic household," and "number of households" (see Figure 2).

Ferguson focuses on the ways in which World Bank reports, as the gold standard of "development" discourse, inevitably seek to depoliticize problems by reframing them as technical challenges which can be met through particular "projects" consisting of supposedly technical solutions: "roads, markets, and credit" (Ferguson 1994:71). This overwhelming focus on the technocratic and apolitical aspects of development helps to stifle discussion about the role of labor, property, and gender in promoting and sustaining existing formations of political power. These more contentious questions are shunted into the "private" realm of the household and, oddly enough, the market as well. Particularly, by pretending that property relationships are a concern of the household and the market and outside of the government's "public" purview (something any Palestinian, Syrian, or Iraqi refugee would have some opinions about), these organizations can help rule out certain kinds of political contestation by stipulating that people submit to putatively apolitical "market" forces.

Moreover, should this demand that people submit to such market forces prove insufficient, there is always the option of casting such questions aside even more forcefully through recourse to ecological explanations that locate the source of certain people's deprivation within "Nature" itself. This actually appears to be a pattern in World Bank reports dealing

\footnotetext{
Figure 2: The same World Bank sponsored Housing Strategy that explained Jordanian building practices as the work of "individual owner-builders" also included a model designed by indigenous planners that explained them as the work of multi-generational households. The research of the indigenous planners, consistently the most plausible contained in the document, was largely not integrated into the overall findings.
} 
Figure 2: Development of a Hypothetical Family

\begin{tabular}{|c|c|c|c|c|}
\hline Year & $\begin{array}{l}\text { Age of } \\
\text { Head }\end{array}$ & Family Milestone & $\begin{array}{l}\text { Numbers of Workers in } \\
\text { Basic Basic Household } \\
\text { (Shelter Unit 1987b:8) }\end{array}$ & $\begin{array}{l}\text { Number of } \\
\text { Households }\end{array}$ \\
\hline 1 & 25 & $\begin{array}{l}\text { Household head marries } \\
\text { and forms household }\end{array}$ & 1 & 1 \\
\hline 2 & 26 & Birth of first son & 1 & 1 \\
\hline 3 & 27 & & 1 & 1 \\
\hline 4 & 28 & & 1 & 1 \\
\hline 5 & 29 & Birth of second son & 1 & 1 \\
\hline 6 & 30 & & 1 & 1 \\
\hline 7 & 31 & & 1 & 1 \\
\hline 8 & 32 & Birth of third son & 1 & 1 \\
\hline 9 & 33 & & 1 & 1 \\
\hline 10 & 34 & & 1 & 1 \\
\hline 11 & 35 & Birth of last son & 1 & 1 \\
\hline 12 & 36 & & 1 & 1 \\
\hline 13 & 37 & & 1 & 1 \\
\hline 14 & 38 & & 1 & 1 \\
\hline 15 & 39 & & 1 & 1 \\
\hline 16 & 40 & & 1 & 1 \\
\hline 17 & 41 & & 1 & 1 \\
\hline 18 & 42 & & 1 & 1 \\
\hline 19 & 43 & First son starts work & 2 & 1 \\
\hline 20 & 44 & & 2 & 1 \\
\hline 21 & 45 & & 2 & 1 \\
\hline 22 & 46 & Second son starts work & 3 & 1 \\
\hline 23 & 47 & & 3 & 1 \\
\hline 24 & 48 & & 3 & 1 \\
\hline 25 & 49 & Third son starts work & 4 & 1 \\
\hline 26 & 50 & & 4 & 1 \\
\hline 27 & 51 & First son marries & 3 & 2 \\
\hline 28 & 52 & Last son starts work & 4 & 2 \\
\hline 29 & 53 & & 4 & 2 \\
\hline 30 & 54 & Second son marries & 3 & 3 \\
\hline 31 & 55 & & 3 & 3 \\
\hline 32 & 56 & & 3 & 3 \\
\hline 33 & 57 & Third son marries & 2 & 4 \\
\hline 34 & 58 & & 2 & 4 \\
\hline 35 & 59 & & 2 & 4 \\
\hline 36 & 60 & Fourth son marries & 1 & 5 \\
\hline 37 & 61 & Household head retires & 0 & 5 \\
\hline 38 & 62 & & 0 & 5 \\
\hline 39 & 63 & & 0 & 5 \\
\hline
\end{tabular}

Assumptions: Males marry at age 25, and enter labor force at age 17 . Mature family contains 4 sons with an average interval of 3 years between male births. 
with contexts that other analysts might term "settler colonialism." In development reports about Jordan and Lesotho, vast differences in geography and environment melt away as a common "ecological" explanation for privation is put forward: basically, too many people on too little arable land. This is despite the fact that, as Ferguson points out, everyone would agree that it would be absurd to give an ecological account of why the Bronx is poor in relationship to Manhattan. Yet ecological accounts abound when discussing Jordan or Lesotho. The fact that the residents have been pushed off of the more desirable land and barred from using it is treated as incidental.

If these reports make dubious claims to provide historical accounts of the recent past, they can nonetheless be studied as indexical traces of the conflicts over housing that have defined Jordan since the 1970 s. ${ }^{10}$ In what follows, it is absolutely essential that we understand what Ferguson calls "the complex relationship between the intentionality of planning and the strategic intelligibility of outcomes" (1994:20-21). The "side effects" of supposedly unsuccessful social engineering projects with seemingly absurd assumptions often extend state power and markets in ways that are all the more difficult to thwart because there is no longer any obvious culprit. The following section will focus on how a more diverse set of actors have worked together to use this notion of the "individual ownerbuilder" and the "private sector" to help land and housing infrastructure achieve their current "commodity candidacy" (Appadurai 1988:15) which is by no means a given. For much of Jordan's recent history, land has proved difficult to buy and sell, remaining largely tied up with marriage exchanges and warfare.

\section{Inventing the Individual Owner-Builder}

A particular ad hoc workgroup of planners known as "the Shelter Unit," in their search for a "Hedonic Index" that would quantify the value of every constituent part of the home, created the powerful (if largely fictitious) figure of the "individual owner-builder" who later became the imagined beneficiary of a generation of housing policy. The erasure of the household as a living, hybrid assemblage of people, labor, property relations, and space and its substitution with the abstracted individual owner-builder is in keeping with "the conceptual polarity of individualized persons and commoditized things" (Appadurai 1988:64). In Appadurai (1988) and 
Kopytoff's (1988) processual framework of commoditization and singularization, anything can achieve "commodity candidacy." The issue is what objects take on these characteristics, under what circumstances, and for how long.

The oral historical register is replete with stories that describe the odd "paths and divergences" through which various things (particularly land) became commodities long before the "era of government" in the 1920s and the later initiatives of development organizations. I will return to this theme in the following section, but for now, one example related to me by my friend Harun about the land-dealing antics of his neighbors' ancestors will suffice:

Muath's grandfather, Ahmed, had a racing horse he would take to weddings and circumcisions back in the days when they had games and races. It was a beautiful horse and he would always win. Suleiman's uncle, Saleem, asked to buy the horse but Ahmed was clever. He said he wouldn't think of selling it. He said, "This is a racing horse" and "Look how beautiful it is." Then Saleem's brother started talking to Ahmed about buying it. Ahmed was clever, though. He knew it was really the brother asking. So he kept saying he wouldn't sell it. Finally, Ahmed sold the horse to the man for 32 dunum of land [32,000 square meters]. That's all the land west of the village! The horse died in the snow that winter but in the end, Ahmed had to sell [all of the land] because of girls.

Confused, I said, "What?" He responded, "Well, in those days, if you didn't have any money, you could give land as bridewealth. So he had a lot of sons and nephews and every time he wanted to marry one, he would give away some of his land to her father until he had almost none left." Harun's story was meant as an object lesson in shifting regimes of value and, of course, as a none-too-subtle way of impugning the neighbors as being, by turns, crafty yet also gullible. The story is part of a moralizing aspect of the genre of oral history that recounts how land, which would now be incredibly valuable, was appropriated via cunning rather than right-only to be lost before the trickster figure could derive any real benefit.

While Harun's account was intended to highlight the naïveté and cupidity of his neighbors, it also reveals that this is not some pre-commodity age of innocence. Land could be bartered with none of the romanticized ideals 
often imputed to gift exchange. People were perfectly ready to use every bit of cunning to swindle their neighbors - even if they never got the opportunity to become millionaires with the help of the turn of the 21st century surge in land values. Timing is everything here. ${ }^{11}$ The story only works as an exercise in 20/20 hindsight, with Saleem judged as particularly stupid for squandering his family patrimony on a short-lived horse and Ahmed judged as particularly crafty for initially making off with the land in this illconceived transaction. Ahmed's subsequent conversion of the property into bridewealth, while completely subscribing to an ethos that valorizes the proliferation of men, is retrospectively denigrated by his neighbors because of the immense price the land in question would now fetch.

As the story makes clear, land was not the same kind of commodity that it is now. Here, the line between singular people and commoditized things is blurred. Land and livestock (much like people) are viewed as a bundle of overlapping rights and responsibilities (cf. Strathern 1985, Weiner 1992). Land won through Ahmed's cunning very quickly and inexorably passes to his agnates and then the families of their respective wives - with very little sense that a man like Ahmed could hope to do anything to stop it. This is all the more true when discussing other people's familial relations. Ownership is perhaps an anachronistic concept here. There is no recourse to the state to challenge other claims: merely the opportunity to defend various rights against other takers.

This form of right (haq) should not be confused with that guaranteed by states. This is rather the form of "right" asserted and upheld through the older form of traditional jurisprudence centered on the ability of male agnatic kin groupings to police the behavior of their own agnates lest they open themselves up to retaliation from rival groups. ${ }^{12}$ It is true that, even within such a system, Ahmed (like so many others in these stories) is able to take control of property using nothing more than a soon-to-be dead horse as pretext. Ironically though, just as Ahmed appropriates the land via cunning against this backdrop of often violent competition among agnatic kin groupings, it simply slips through his fingers as his various family members make all manner of claims on that land before it can become the kind of state-protected private freehold property that would now earn Ahmed and his descendents a small fortune.

The World Bank would try to construct a very different regime of value called a Hedonic Index: an exercise in market research that seeks to understand individuals (who independently control things that can be 
conceptualized as private freehold property) in relationship to those things via a precise numerical scale of value. It would be easy to dismiss the exercise as pointless (people could relate horses to land in quantitative terms decades before the World Bank showed up). The numerical values themselves are a distraction: even the Shelter Unit did not fully believe the results. At times, the authors of the report seem utterly convinced that the respondents were systematically lying to them in hopes of gaining assistance. ${ }^{13}$ It was the far broader conceptual work of singularization and commoditization, summed up on the figure of the individual owner-builder that was truly transformative.

Knowledge practices like surveys and hedonic indices are essential to the construction and maintenance of infrastructure. As Donald MacKenzie argues in his "Ten Precepts for the Social Studies of Finance," facts matter and, more importantly, "facts are made: by experiment, by intellectual work, and by observation that is normally technologically mediated and typically is disciplined and goal-oriented rather than haphazard" (2009:9). However, the cognitive infrastructure of even the most powerful and wellfinanced institutions like the World Bank are rarely sufficient to dictate the unfolding of events. To be sure, their economic models are often "performative," shaping and formatting as much as they observe. However, in Jordan their models soon came into conflict with competing infrastructures: namely those of families more interested in finding stable sanctuary for themselves and their progeny (the proliferation of men) than the intricacies of land tenure and housing markets (the proliferation of wealth).

As the World Bank worked to house a rapidly sedentarizing Bedouin population and a large population of displaced Palestinians, they formulated the problem as one of creating an efficient housing market, which would provide the credit necessary to meet demand. Yet land and housing were anything but the freely circulating commodities that the Bank assumed they were dealing with. Likewise, people were not the fixed, autonomous, and grounded (that is singular) "individual owner-builders" that the Bank assumed they were dealing with. With many people who loathe the idea of moving away from their families or using land as collateral (not just due to Islamic strictures around moneylending, but also familial disapprobation), the dream of an efficient, frictionless housing market remained a fantasy. To make matters worse, the Shelter Unit and its backers at the World Bank found themselves dealing with the fact that considerable amounts of marginal communal (mushā') land claimed by a large tribe 
known as the Bani Hasan were sitting next to rapidly growing refugee camps. This was allowing these groups to do an end-run around the government's property registration system and the banking sector, making complex, inscrutable arrangements amongst themselves instead.

As long as property rights were in question, people would be forced to see property through the lens of communal defense. The proverb, "the proliferation of men is better than the proliferation of wealth" epitomizes this sensibility that wealth is worthless without people to defend it. An organization that asks accused squatters and people who see themselves as inhabiting ancestral lands to put a monetary value on their homes may at first appear to be getting ahead of itself. Nonetheless, the Shelter Unit and its backers still exerted an outsized effect on a key aspect of JordanianPalestinian relations by getting deeply involved in the conjoined tasks of land registration and infrastructure provision. In fact, they tacitly participated in the legitimation of certain Palestinian refugees' efforts to permanently settle in Jordan-all while generating profits for global financial markets as long as these refugees continued to repay the loans to the Bank as a condition of their continued residency in the homes that they had built.

\section{"Land Was Free"}

There could not be a "proper" housing market until land had become a different kind of commodity-specifically one that could be defended as property by an individual with recourse to the repressive apparatus of the state. In other words, it had to become private property. Much of this contestation in the western part of Jordan near the Jordan Valley happened in the 1930s when the British performed a cadastral survey and registered agricultural lands. While both Ottoman law and local practice conferred property rights conditional on continued use and improvement of the land, the land near the valley received enough rainfall to ensure that someone would be regularly availing themselves of the land for agricultural purposes. This, of course, was and is increasingly difficult the further east one travels. Traveling east on the road to Zarqa, the landscape shifts from green to brown. Out there, it was not even possible to farm the land for three consecutive years - the minimum time required to register land under the mushā' system, which outlived the Ottoman and British empires and passed, largely unremarked upon, into Jordanian property law. However, with the post-independence explosion in the size of the state's 
bureaucracy (especially in the capital of Amman), the construction of a large military installation in neighboring Zarqa, and the influx of wave after wave of refugees, this land was transformed from wasteland into some of the most valuable real estate in the Middle East in a matter of decades.

As Anne Marie Baylouny (2008) argues in the article "Militarizing Welfare," men hailing from the East Bank (especially in rural areas) have been increasingly absorbed into the security services where they continue to act out a defensive role but now serve new masters: the state rather than their families. In return, they have been able to shore up their individualistic control of property through both the system of private property ownership and their differential access to cash (due to their government jobs). At the same time, foreign migrants have increasingly taken over more traditional forms of female labor in agriculture and animal husbandry, leaving women from particular class backgrounds increasingly confined to the home as the older rationales for their movement throughout the community have disappeared. For Bedouins in particular, housing has been transformed from women's wealth (a goat hair tent woven by the family's women) to men's wealth: the concrete house built with the labor and money of primarily male family members. Meanwhile, communities of various refugee groups have tended to cluster in urban areas where most men take what jobs they can get in the private sector. The lucky ones work abroad and send back remittances or, increasingly, administer investment projects backed by international financial actors within Jordan. The imposition of an efficient security apparatus, in tandem with bureaucratization, changing forms of domestic architecture, and new property regimes has led to a reconfiguration of gender roles. This reconfiguration modulates men's defensive role and renders it increasingly problematic, but does not eliminate it.

The notion of seizure remains important here. In the moralizing aspect of the genre of stories about land, there is always a heavy taint of illegitimacy-especially where money is involved. This is to be expected since shifts in property relations tended to track closely with social upheaval. New interlopers were disruptive. ${ }^{14}$ Yet, disruptions were inevitably reconceptualized later in terms of the emergent Jordanian state in relationship to its geopolitical allies and competitors. The stories had a geographic as well as a moral logic. From the east came raiders and extortionists: this was a reference to the fact that, during the 1930s, certain Saudi tribes would decimate the herds of southern Jordanian Bedouins and then take cover underneath the British defensive umbrella. ${ }^{15}$ From the west came 
swindlers and loansharks: useful villains for a nationalist rhetoric that claims "Jordan for Jordanians" to the exclusion of Palestinian refugees. This example from the moralizing aspect of the genre of oral historical accounts of land sales is typical:

I remember stories from those days in the past but not clearly. It's like a dream to me. I grew up hearing about these things in the 1970s. So people would come from Palestine and people would buy all sorts of stuff with land. Dates, olive oil, ḥalāwa [a sugary sesame paste with questionable nutritional value], finely embroidered underwear...

After the ensuing uproar, he continued, somewhat more seriously:

Land back in those days was basically free (balāsh) and the people were hungry. People would die from hunger. So these traders would come from Palestine with dates, olive oil, preserves, and ḥalāwa. Imagine if you were dying of hunger and someone brought you a tank full of halāwa. You'd be beside yourself, right? The [neighboring tribe] sold so much of their land for halāwa.

Once again, in keeping with the moralizing aspect of the genre, it is always about other people and the narrative is driven by a combination of licentiousness, venality, and cunning on all sides.

The imputation of great cunning on the part of the Palestinian merchants is consonant with a tendency within Jordanian nativism to see rural East Bankers as hospitable and naïve in relationship to the depredations of interloping Palestinian city-folk (Shryock 1997a, 1997b). Yet there were reasons for skepticism: what could a travelling merchant in possession of luxury goods who was operating beyond the reach of the state do when desperate locals wanted things they could not afford to pay for? But from the perspective of the East Bankers like Harun:

You see, these traders were like [a particularly notorious local figure who was part village head and part moneylender]. See, he had a store and he would lend [money] and not harvest [the debt] (yidayin wa ma yahsid). Then he would wait for a bad year and ask for the money. They wouldn't have anything to give him but their land. Isn't that religiously forbidden (harām)? But there was a Palestinian who 
did this even more. His name was [so-and-so] Al-Nabulsi. He would let the [neighboring tribe] buy on credit and then suddenly he would ask for his money and take the land as payment. Isn't that harām? He ended up with 400 dunum among the [neighboring tribe]! He had three sons and they divided it between them. One of them was a drunk in Madaba who sold all of his, but the other two still have all of their shares.

Based on generic conventions, it is certainly only a matter of time until some misfortune befalls the other two or, at the very least, some more of their descendants. ${ }^{16}$ But, of course, Al-Nabulsi and the village moneylender (along with their descendants) would probably have to rank as some of the luckier traders in history. If they had tried to seize such lands in the absence of the state's subsequent imposition of the current regime of private property, it would have been the best solution to their disagreements with their customers, but they would not have reaped such outsized rewards. Like the thwarted trickster figure, Ahmed, they would have either watched as the land they had wrested control of was absorbed into the community as it was re-divided to cover all manner of social obligations or they would have simply been pushed off by someone more aggressive and with more local support.

\section{Of Squatters and Chaotic Housing}

Land is not necessarily valuable. What is the use of having dry, unpopulated space with no electricity, roads, or sewerage? There is a popular origin myth about the Bani Hassan (who will figure prominently in the following account), which tells that the people were hungry and thirsty and begged a man from the Bani Hassan to help them find water for their crops. He told them that he would find them water: his cow would walk until it found the nearest well. But in return, he would get all of the land between the spot on which he stood and that well. That, it is often said, is how the Bani Hassan came to own the most land in Jordan: the most land, perhaps, but also the most useless land. So imagine their delight when a city suddenly began to spring up around them after the waves of Palestinian refugees arrived. Then consider the sense of deep betrayal they must have experienced when the government not only tried to stop them from selling their lands to the settlers, but actually challenged their ownership claims. This 
struggle is at the center of Omar Razzaz's (1991) ${ }^{17}$ Ph.D. dissertation Law, Urban Tenure, and Property Disputes in Contested Settlements: The Case of Jordan, which has come to be the definitive contemporaneous account of the Bani Hassan's struggle with the Jordanian state. His account will help explain how the World Bank's quest for efficient markets would have a profound effect on the development of housing infrastructure east of Amman, bringing a close to an, at times, violent conflict between the state, longtime residents, and newcomers. The World Bank would effectively do this by taking out a loan and using it to provide legal title and some infrastructure to those occupying the land-so long as they repaid the loan.

Razzaz, like the World Bank Planners, was highly cognizant of the fact that it was the very undesirability of this land that made it so cheap and hence attractive for those aspiring to join the propertied middle class. As he notes, 90 percent of legally available residential property at the time was zoned for large upper-income plots (1994:16). Many of these plots could not be legally subdivided any smaller than 1,000 square meters. Meanwhile, the government had built Yajouz Road to connect the two cities of Amman and Zarqa, providing a transportation hook-up to a large expanse of arid steppe with questionable ownership status. This helped underwrite the massive expansion of the Jordanian middle class and a particular gendering of labor, property, and space. By the 1980s, the goat hair tent woven by women was a thing of the past and virtually every segment of Jordanian society sought permanent concrete houses built by men leveraging their access to the cash economy. Razzaz documents how the housing boom in Yajouz took the pressure off of the more legitimate housing market in other parts of the country, leading prices in Yajouz and elsewhere to converge by the end of the 1980s. Thus, even those with no stomach for the risks associated with squatting came to benefit from lower housing prices and greater liquidity in the market across the country that made permanent concrete houses more accessible to more Jordanians. As the land in Yajouz was connected to infrastructure, zoned, and registered, it became a different kind of commodity. Most importantly, it became the kind of commodity that could be traded by global financial institutions.

People began to build houses along Yajouz Road sometime in the 1970s. The materials could be moved into place by vehicle. Residents could bring in generators for electricity and turn to a preexisting network of water trucks. Sewerage could be handled with septic tanks. Members of the Bani Hassan enthusiastically sold plots to all takers using a sale 
contract (hujja) without the government deed (sanad), which has been required since the Ottoman tanzimat reforms. The Jordanian government objected vociferously to such sales, but the Bani Hassan were unrepentant. They watched as tribesmen allied more closely with the regime in the western arable zone made millions selling land that was registered, zoned, and provisioned with water and electricity. Razzaz records one man who reasoned, "Islam tells us...if an unjust father treats his sons differently, feeding one and starving the other, the hungry son is permitted to seize his share, even if he has to steal it from his unjust father to survive. This is all we are doing" (1994:18).

When the government tried to demolish the houses of the Bani Hassan in 1983 to stop unregistered building by people who lacked legal title, the latter took up arms, shot at the security services, and burned their vehicles. When tribesmen were rounded up, their families rioted outside the jail. Various attempts at reconciliation followed, and building and demolition continued, but with a new rule: if the roof was finished, the house was to be left intact. By 1985, the area was in the midst of a building boom. People would wait until Thursday afternoon when the police went home for the weekend. If they could finish the roof before the police returned, the authorities would generally not move forward with demolition. Razzaz reports that people clustered together, often based on kin ties or common place of origin. He gives the example of a "Hebron"18 community, which would take up a collection to bring in more gravel for their road every year. And, of course, Razzaz emphasizes the sense of security that living together engendered. Residents drew on the moral vocabulary of the host/ guest relationship. The "hosts" from the Bani Hassan made promises to continue to help the buyers defend their rights long after the sale had been made, although this was no substitute for the certainty that came with official registration and title deed (sanad) in addition to the more traditional hujja or sale deed. One tribesman explained to Razzaz, "We do not think of a hujja as a regular sales contract. It is more like a marriage contract, binding both the buyer and seller for good" (1994:24).

It would be wrong, however, to think that there was universal agreement on the nature of the problem. For the World Bank and their "squatter settlement standardization program," the problem was clearly one of property rights and the solution was to implement putatively apolitical initiatives of housing market "rationalization." However, the indigenous planners always referred to the problem as one of sākin 'ashwa'i (chaotic housing), using a 
word with no ostensible connection to property rights. For veterans of that era, the chief goals of the project had always been "straightening out the lines," "widening the roads," and "organizing things." The property relations, central to the World Bank's concerns were an afterthought for local planners who saw increasingly dense settlements with no signage, unreliable roads, and no services. The settlements were closed off and inscrutable, and this worried employees at the HUDC. ${ }^{19}$ Razzaz, a future World Bank executive, is a sophisticated observer of both the Bank and indigenous officials, and captures traces of this divergent focus in his contemporaneous account. He reports that, "the situation was always described as chaotic, a 'grave threat to law and order,' a 'potentially explosive situation where disputes between neighbors, heirs, and contesting claimants, could turn bloody and set the place on fire'" (1994:26-27). As a careful reading of Razzaz's account of the stance taken by local officials makes clear, the issue of ownership was largely subordinated to that of public order, only arising where "contesting claimants" might "set the place on fire."

It was into this breach that the World Bank stepped. With nearly every sector of Jordanian society (to say nothing of the international community) increasingly accepting that the Palestinians were not leaving Jordan and would expand beyond the refugee camps and eventually fill in the space between Amman and Zarqa, the World Bank offered the following solution: the Jordanian government would take out a loan from the Bank, subdivide all of the plots in the squatter settlements, officially register the plots, provide some infrastructure (roads, water, and electricity), and then make the residents repay the loans. This would please many. The Bani Hassan could sell their land, the government created all sorts of jobs and opportunities for patronage, and, whether or not any given individual could pay back the loan, there was a delimited commodity asset that could be seized as collateral to either encourage repayment of the loan or to sell to clear the balance sheet.

As another veteran of that era in the organization recalled, "it was great for everyone...except maybe the people who are still paying off the loans." Particularly, from the government's perspective, it reasserted the older Ottoman principle of the state's prerogative in extracting some sort of fee from those who occupy land-here reformulated as principle and interest rather than a tax. Of course, from another perspective, this was the last land within physical reach of regular employment opportunities in the capital that was sheltered from global commodity markets due 
to its questionable ownership, zoning status, and lack of infrastructure. Increasingly, Jordanians must compete in the same housing market as oil sheikhs, technocratic nouveau riche, hedge funds, and even their uppermiddle class neighbors who have high enough salaries to pay off a mortgage while still having enough money left over for food.

\section{Conclusion}

Over the course of the past century, an ideal has emerged in Jordan which has valorized a certain kind of markedly masculine individual who could singlehandedly go out and earn the money necessary to provide for his household and, thereby, assume a highly qualified form of sovereign control over that household. In the process, the proliferation of wealth has seemingly gained importance in relationship to the proliferation of men. This has led, in turn, to the proliferation of a certain kind of man who could properly husband his wealth and his progeny as part of a long-term strategy of accumulation. Of course, this type of control came from both male differential access to cash as well as male confidence in the state's willingness to defend their property-the true embodiment of sovereignty within contemporary Jordan. Such an arrangement was, in some ways, unprecedented. Many of the ties entailed by older notions of property relations were sundered. Housing became stationary and shifted from being women's wealth (the goat hair tent) to men's wealth (the immovable concrete house). Most notably, for the first time, large numbers of previously impoverished men suddenly discovered that they could afford to provide housing and food for their wives and obviate the necessity that the latter circulate through the community. In this, men like Abu Mahmud could aspire to partake in a classic pre-modern marker of nobility.

As stated in the introduction, never once did Abu Mahmud tell me who his father and his friends had purchased the land from. A few times, when I impudently pressed the issue, he would scoff and exclaim, min nās (from people), with a dismissive wave of his hand. Categorically uninterested in explaining the finer points of the property transactions that legitimated these claims in the eyes of the Jordanian state, he focused on what he saw as truly key to ownership over the longue durée: the changing masculine qualities of himself and his ancestors. He lionized the latter as "real men," returning again and again to stories of his father, Sweilim, and his notorious forefather: 
[His tribe] would go wherever they wanted. They bought [the area] from [another well-known tribe]. Those were the days of so-and-so Al-Aswad...He was a real man (rajul gadd-hālu). He was a Sheikh. He would take the hind leg of the lamb from every house. He was recognized by the Ottomans. He ruled over this whole area. $\mathrm{He}$ took a quarter of the goats. He would go from house to house and if they didn't give him his right, he would make them thresh thistles [by walking barefoot on piles of thistles like donkeys separating wheat from chaff].

Such was the difference between his forefathers' era-the era of real men (men the size of themselves)-and the more debased times in which we now lived, where men had grown comparatively soft and complacent.

For Abu Mahmud, the buying and selling of the land (the relations between putative commodities) remained trivial compared to the relations between men. His agnates, in his account at least, could go wherever they wanted before the "sale" of the land in question. Even where land was "bought" it was the collective act of agnates relating to another group of agnates through at times violent confrontation. The salient historical precedent was a man who could command a hind leg from every house, the recognition of the area's would-be Ottoman overlords, and the fear of anyone who did not want to be sadistically tortured in a cruel public spectacle that reduced them to the status of an animal.

At a time when there is little reason to believe housing will get any more affordable, with the ongoing Syrian conflict and the emergence of the Za'atari and Azraq refugee camps as increasingly permanent settlements, one has to wonder if the role of seizure might begin to assert itself more forcefully in the coming years. A tenuous compromise between the dual imperatives of the proliferation of men and the proliferation of wealth, working in harmony for now, may see the aims of these two imperatives begin to diverge again. It remains to be seen if Abu Mahmud is correct in asserting that the proliferation of men is better than the proliferation of wealth. 


\section{Endnotes:}

${ }^{1}$ Mitchell's "The Work of Economics" (2005) reminds us that economics and finance themselves have found this movement between center and periphery quite generative. He chronicles how the economist Hernando de Soto (2000) used a particular squatter settlement standardization program in Peru as a "natural experiment" to valorize liberal economics' assumption that the extension of property rights is essential to development. In contrast, Mitchell argues that the putatively positive effects of the program uncovered by de Soto probably had more to do with the way the design of the studies interacted with the conclusion of Peru's war with the Shining Path guerrilla movement and broader liberalization initiatives. In debunking de Soto's findings, Mitchell offers a fascinating micro-history exemplifying how relatively peripheral communities can come to be central to the legitimation of the broader economic order, that order's reliance on markets, and its peculiar sort of property regime. For a detailed account of the relationship between market-formation, conflicting social orders, and warfare in the longue durée, see Graeber (2011).

${ }^{2}$ Tsing's Friction (2004) offers one of the most compelling contemporary ethnographic accounts of the relationship between capitalism and violent resource extraction in frontier zones.

3Zaloom's (2006) vivid and widely-cited portrayal of the almost-exclusively male "open-outcry" traders who physically jostle in trading pits to make the best possible trade is a notable exception that nonetheless epitomizes the more general trend. Because the participants are rather well-remunerated and the actual commodities are so distant from the site of struggle, the violence involved is reduced to a quaint and abstract game that (in any event) is rapidly being replaced by new computer interfaces that demand an alternative form of bodily hexis that is almost completely sedentary.

4 Lars Wahlin $(1988,1994)$ and Shryock (1997a) have questioned the degree to which Ottoman records can be trusted-where they still exist. For instance, Fischbach (2000:31) points out that the land records for southern Jordan were burned during an uprising in Karak in 1910. This implies that these records were not necessarily either irrelevant or uncontroversial. The case for the veracity of the later records is stronger, but there is probably a degree to which the British cadastral survey of the 1930s both reconfirmed the existing situation (cf. Shryock 1997a) but also became a sort of self-fulfilling prophecy. By simultaneously registering property to discrete individuals, effectively putting a stop to raiding and then distributing titles, government jobs, and education to many of those same individuals, the British probably tended to ossify social distinctions, labor relations, and property rights.

5 Mitchell (2002) provides a detailed account of the British cadastral survey of Egypt in Chapter 2 ("Principles True in Every Country"), which emphasizes similar sensibilities.

${ }^{6}$ My neighbors would make a point of eating from these fruit trees when the opportunity presented itself. When doing so, they would remind me that, according to the sunna (the sayings and actions of the Prophet Muhammed), it is permissible to pick fruit from any fruit-bearing plant on anyone's land as long as it is eaten immediately and not taken away.

7The apparent contradiction between Polanyi's notion of land as a "fictitious" commodity and Appadurai (1988) and Kopytoff's (1988) model of commoditization can be dispensed with so long as we treat the latter's notion of "commodity candidacy" as a sort of conceptual limit that actual objects embedded in social relations can only approach asymptotically.

${ }^{8}$ These planners moved between private consultancies, various ministries, the Housing Corporation, the Amman Municipality, the Housing Bank, USAID, and the World Bank.

9The official position of the Executive Summary of the National Housing Policy on the Palestinian Question deserves to be quoted at length: "Whether or not there is a resolution of the political question, refugee camps in urban areas at least, are clearly becoming permanent features of the housing stock. Government should therefore consider policies for upgrading refugee camps with the view that they will continue to function as permanent urban areas even if a large number of their present inhabitants were to leave" (Shelter Unit 1987a:32). What I find revealing here is the tenacity with which the Shelter Unit attempts to shield property relations from the contagion of "political questions."

10The fact that the English-language reports were produced on 8.5 " by 11" paper and not A4 always seemed emblematic of their foreignness. In fact, when I had finished with the 24-volume National Housing Strategy from 1987, a number of employees were curious to hear what was in it.

${ }^{11}$ The way that the imposition of new property regimes renders the land involved in these moralizing tales far more valuable now than at any point in the past is central to how these stories appeal to the mix of envy, sour grapes, and Schadenfreude that makes them so much fun to both hear and tell. 
12This notion of rights being underwritten by agnatic kin groups observing a traditional code of "Bedouin Justice," as opposed to an organized state, is central to the work of the anthropologist, former intelligence officer, and opposition politician Ahmad Oweidi Al-Abbadi (2006).

13The unreliability of interviewees was discussed extensively in Volume 9: "The Housing Suppliers Survey," but, otherwise, the findings are generally reproduced without any caveats throughout the rest of the report.

14The moral logic is strikingly consonant with Sahlins's (1972) "On the Sociology of Primitive Exchange."

${ }^{15}$ Alon (2007) weaves together oral and textual evidence to provide a thorough account of conflicts which defined the relations between Jordanian and Saudi tribes during the British Mandate.

16See Taussig (1977) on ill-gotten wealth that cannot bear fruit.

${ }^{17}$ Razzaz would later go on to teach at MIT and run the World Bank's Lebanon office.

$18 \mathrm{Hebron}$ is the name of a longstanding Palestinian settlement that Jordan lost to Israel during the Six-day War in 1967.

${ }^{19}$ This is in keeping with a transnationally circulating planning discourse about the dangers of informality (cf. Holston 2007, Bayat 1997).

\section{References:}

Al-Abbadi, Ahmad Oweidi. 2006. Bedouin Justice: The Customary Legal System of the Tribes and its Integration into the Framework of State Polity from 1921-1982. Amman: Dar Jareer.

Alon, Yoav. 2007. The Making of Jordan: Tribes, Colonialism, and the Modern State. New York: I.B.Tauris.

Appadurai, Arjun. 1988. "Introduction: Commodities and the Politics of Value." In Arjun Appadurai, ed. The Social Life of Things: Commodities in Cultural Perspective, 3-63. Cambridge: Cambridge University Press.

Bayat, Asef. 1997. "Un-civil Society: The Politics of the 'Informal People." Third World Quarterly 18(1):53-72.

Baylouny, Anne Marie. 2008. "Militarizing Welfare: Neoliberalism and Jordanian Policy." Middle East Journal 62(2):277-303.

Bear, Laura, Karen Ho, Anna Tsing, and Sylvia Yanagisako. 2015. "Gens: A Feminist Manifesto for the Study of Capitalism." Fieldsights - Theorizing the Contemporary (blog), Cultural Anthropology Online, March 30. Accessed from http://www.culanth.org/fieldsights/652-gens-a-feminist-manifesto-for-thestudy-of-capitalism on June 29, 2016.

Callon, Michel. 1998. The Laws of the Markets. Oxford: Blackwell Publishers.

Ferguson, James. 1994. The Anti-politics Machine. Minneapolis: University of Minnesota Press.

Fischbach, Michael R. 2000. State, Society, and Land in Jordan. Leiden: Brill.

Goldman, Michael. 2005. Imperial Nature: The World Bank and Struggles for Social Justice in the Age of Globalization. New Haven: Yale University Press.

Graeber, David. 2011. Debt: The First Five Thousand Years. New York: Melville House.

Harvey, David. 2003. "Accumulation by Dispossession." In The New Imperialism, 63-87. Oxford: Oxford University Press.

Hijmans, Robert, Susan Cameron, Juan Parra, Peter Jones, and Andy Jarvis. 2005. "WORLDCLIM: A Set of Global Climate Layers (Climate Grids)." In World-Clim -Global Climate Data. Accessed from http:// www.worldclim.org on Jan 6, 2016.

Ho, Karen. 2009. Liquidated: An Ethnography of Wall Street. Durham: Duke University Press.

Holston, James. 2007. Insurgent Citizenship: Disjunctions of Democracy and Modernity in Brazil. Princeton: Princeton University Press.

Kopytoff, Igor. 1988. "The Cultural Biography of things: Commoditization as Process." In Arjun Appadurai, ed. The Social Life of Things: Commodities in Cultural Perspective, 64-94. Cambridge: Cambridge University Press.

Luxemburg, Rosa. 2003 [1912]. The Accumulation of Capital. Agnes Schwarzschild, trans. New York: Routledge Press. 
MacKenzie, Donald. 2006. An Engine, Not a Camera: How Financial Models Shape Markets. Cambridge: MIT Press. Press.

2009. Material Markets: How Economic Agents are Constructed. Oxford: Oxford University

Marx, Karl. 1976 [1868]. Capital: A Critique of Political Economy, Vol. I. Ben Fowkes, trans. New York: Penguin Press.

Mitchell, Timothy. 2002. Rule of Experts: Egypt, Techno-politics, Modernity. Berkeley: University of California Press.

2005. "The Work of Economics: How a Discipline Makes its World." European Journal of Sociology 46(2):297-320.

Miyazaki, Hirokazu. 2005. "The Materiality of Finance Theory." In Daniel Miller, ed. Materiality, 165-181. Durham: Duke University Press.

Polanyi, Karl. 1944. The Great Transformation. Boston: Beacon Press.

Proudhon, Pierre-Joseph. 1994 [1840]. What is Property? Donald Kelley and Bonnie Smith, trans. Cambridge: Cambridge University Press.

Razzaz, Omar. 1991. Law, Urban Tenure, and Property Disputes in Contested Settlements: The Case of Jordan. Ph.D. Dissertation, Department of Urban Planning, Harvard University.

. 1994. "Contestation and Mutual Adjustment: The Process of Controlling Land in Yajouz, Jordan." Law and Society Review 28(1):7-39.

Sahlins, Marshall. 1972. Stone Age Economics. New York: Aldine Publishing Company.

Shelter Unit. 1987a. "Executive Summary." National Housing Strategy. Amman: Ministry of Planning. . 1987b. "Existing Housing Situation in Jordan: Technical Memorandum Number Seven." National Housing Strategy. Amman: Ministry of Planning.

Shryock, Andrew. 1997a. "Bedouin in Suburbia: Redrawing the Boundaries of Tribalism and Urbanity in Amman, Jordan." Arab Studies Journal 5(1):40-56.

. 1997b. Nationalism and the Genealogical Imagination: Oral History and Textual Authority in Tribal Jordan. Berkeley: University of California Press.

Soto, Hernando de. 2000. The Mystery of Capital: Why Capitalism Triumphs in the West and Fails Everywhere Else. New York: Basic Books.

Strathern, Marilyn. 1985. "Kinship and Economy: Constitutive Orders of a Limited Kind." American Ethnologist 12(2):191-209.

Taussig, Michael. 1977. "The Genesis of Capitalism amongst a South American Peasantry: Devil's Labor and the Baptism of Money." Comparative Studies in Society and History 19(2):130-155.

Tsing, Anna. 2004. Friction: An Ethnography of Global Connection. Princeton: Princeton University Press.

Wahlin, Lars. 1988. "The Occurrence of Musha' in Transjordan." Geografiska Annaler. Series B, Human Geography 70(3):375-379.

. 1994. "How Long has Land Been Privately Held in Northern Balqa', Jordan?" Geografiska Annaler. Series B, Human Geography 76(1):33-49

Weiner, Annette. 1992. Inalienable Possessions: The Paradox of Keeping-While-Giving. Berkeley: University of California Press.

Yanagisako, Sylvia. 1979. "Family and Household: The Analysis of Domestic Groups." Annual Review of Anthropology 8:161-205.

Yanagisako, Sylvia and Carol Delaney. 1995. Naturalizing Power: Essays in Feminist Cultural Analysis. New York: Routledge.

Yiftachel, Oren. 2009. “Theoretical Notes on 'Gray Cities': The Coming of Urban Apartheid?” Planning Theory 8(1):88-100.

Zaloom, Caitlin. 2006. Out of the Pits: Traders and Technology from Chicago to London. Chicago: University of Chicago Press. 


\section{Foreign Language Translations:}

The Proliferation of Men: Markets, Property, and Seizure in Jordan

[Keywords: Infrastructure, squatter settlements, settler colonialism, violence, kinship, masculinity]

人之繁衍: 市场, 财产, 与癫㾁在约旦

[关键词：内部结构，棚户区，迁占殖民主义，暴力，亲族关系，阳刚特质]

A Proliferação de Homens: Mercados, Propriedade, e Confisco na Jordânia

[Palavras-chave: Infraestrutura, posseiros de assentamentos, colonialismo de assentamento, violência, parentesco, masculinidade]

Распространение мужчин: Рынки, имущество и конфискация в Иордании

[Ключевые слова: инфрастуктура, скваттерные поселения, поселенческий колониализм, насилие, родство, маскулинность]

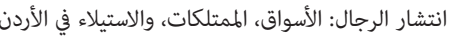
كلمات البحث: البنية التحتية، المستوطنات العشوائية العائ، الاستعمار الاستيطاني، العنف، القرابة، الذكورة 